\title{
Population Abundance and Distribution of Ectoparasitic Plant Nematodes Associated with Apple Trees (Malus domestica) in Apple Belts of Kashmir, India
}

\author{
G. M. Lone*, F. A. Zaki, S. S. Pathania and Sajad Mohi \\ Department of Entomology, Faculty of Horticulture (S.K.U.A.S.T.-K), India \\ *Corresponding author
}

A B S T R A C T

\begin{tabular}{|l|}
\hline K e y w or d s \\
$\begin{array}{l}\text { Population Abundance, } \\
\text { Ectoparasitic Plant, Apple } \\
\text { Trees (Malus domestica) }\end{array}$ \\
\hline Article Info \\
\hline $\begin{array}{l}\text { Accepted: } \\
\text { 25 May } 2018 \\
\text { Available Online: } \\
\text { 10 June } 2018\end{array}$ \\
\hline
\end{tabular}

Fruits as a back bone of horticulture are grown over an area of 5.50 million hectares in our country with a production of over 55 million metric tones per year. Our country accounts for $10 \%$ of the total world production. Among various fruits, apple being the pre-dominant temperate fruit of India accounts for about $3 \%$ of the total fruit production of the country. India stands $8^{\text {th }}$ in apple production in the world but ranks at $53^{\text {rd }}$ position in terms of productivity (FOA, 2007). In India average productivity of apple is nearly 6-8 tonnes per hactare which is lower than the average yield of advanced countries. e.g. Belgium (46.22 tons/ha), Denmark (41.87) and Netherland (40.40 t/h). Among the temperate fruits in Jammu and Kashmir, apple ranks $1^{\text {st }}$ covering $43.30 \%$ area and $80.18 \%$ production respectively. (Anonymous, 2008). In the state, Kashmir valley is rich in flora and fauna and it is the largest apple producing region in the country and at present apple industry has become the backbone for Kashmir's rural economy, generating employment to thousands of people besides providing multinutrtional security.

\section{Introduction}

In Kashmir among the major districts viz Baramullah, Shopian and Kupwara, the Baramullah district ranks $1^{\text {st }}$ in apple production. Yield of apple has been showing an increase trend from 4.12 to $10.72 \mathrm{~m}$ tones per ha during. (1975-2008) but the productivity of apple in $\mathrm{J} \& \mathrm{~K}$ fluctuated between 9-11 M. T. or less since last sixteen years (Banday, et al., 2009) which is the cause of serious concern to the fruit growers, research workers and development agencies. Several factors are attributed to this trend in productivity and among which incidence of diseases and pests, in apple cultivation is emerging as a serious threat to apple orchards in the valley.

Among the various pests and diseases, the information on nematodes parasitizing on apple trees and their role in fruit damages is scanty (Wali-ullah \& Koul, 1989) and which constitutes one of the most important group of animals under a separate phylum Nematoda and from which the class adenophorea, includes important plant ectoparasitic nematodes, predisposing plants to many fungal, bacterial diseases and as vectors of several soil born plant viruses. becoming 
responsible for qualitative and quantitative losses to fruits and the extend to which knowledge in this field has advanced can be judged from the reviews of Cadman (1963), Pitcher (1965) and Bajaj and Jairajpuri (1979).

Due attentions has not been paid yet in the valley and in view of paucity of information regarding their frequency, density, prominanace value, systematic studies of these plant parasitic adenophoreans associated with important woody perennial fruit crops in various fruit orchards of Rafiabad, the important fruit belt of North Kashmir, was essential to evolve economically feasible control measures suiting to the local conditions so that the much advocated lab to land programme can become a practicability in future and also to become a base line data for further research work.

\section{Materials and Methods}

During summer (June, Jully and August, 2008) an extensive of plant parasitic adenophoreans associated with apple trees was conducted at nine fruit orchards in all three villages (Ferozpora, Ladoora and Rebon) of fruit belt Rafi-abad of North Kashmir. At each location (Village) three fruit orchards having almost same topography (Plains), same kind and same aged apple trees were selected. From each orchard three apple tree were selected at random and one sample was collected from each tree.

Thus a total of 27 samples were collected and each mixed sample consisted of three sub samples collected randomly away from the base of 25 year apple trees within its periphery. at $50 \mathrm{~cm}$ depth. Nematodes were extracted from $250 \mathrm{cc}$ soil sample by cobb sieving and decanding method (Cobb. 1918) using sieves of $18,90,150 \& 200$ mesh followed by modified Baermann`s funnel technique (Christie \& Perry, 1951) The nematodes were heat relaxed, killed, fixed in F: A $(4 ; 1)$ and stored at $10-15^{\circ} \mathrm{C}$ for further studies within a weeks period. The nematodes were identified upto genus and species level on the basis of morphological characters. and absolute and relative density, frequency, prominence value, importance value, biomass and range of each adenophorean species was determined (Norton, 1978) and diversion of density index of adenophorean population was also determined on the basis of population abundance as follows.

No. of samples containing species/genus Absolute

Frequency of sp./ genus $\mathrm{X}=$ x 100 No. of samples collected.

Relative

Frequency of species/genus

Frequency of sp. / genus $\mathrm{X}=$ $\times 100$ Sum of frequencies of all spp/genus.

Present in samples

No. of individuals of $\mathrm{x}$ in a sample Absolute

Density of sp. / genus X = ----------- $\times 100$ Volume or mass or unit of sample.

No. of individuals of sp. / genus in a sample Relative

Density of sp. / genus $\mathrm{X}=$ $\times 100$

Total no. of individuals of all spp/genus. in a Sample.

Prominence value of sp. / genus $\mathrm{X}=$ Absolute density $\sqrt{\text { Frequency }}$

Biomass of sp. $/$ genus $x=a^{2} b / 16 \times 10^{5} \mu \mathrm{g}$.

( $\mathrm{a}=$ average greatest body width, $\mathrm{b}=$ average body length of a nematode in $\mu \mathrm{m}$ )

Importance value $=$ Relative frequency + Relative density + Relative biomass 
The Shannon Weiner density index formula was also applied.

Shannon`s diversity index $(\mathrm{H})=\sum_{\mathrm{i}=1}^{\mathrm{s}} \mathrm{Pi}$ In Pi, where

$\mathrm{s}=$ number of species / genus at each location.

$\mathrm{Pi}=$ relative abundance of $\mathrm{ith}$ species / genus.

In=Natural Logarithum of $n(\log$ with base e)

\section{Results and Discussion}

It is found that in $95 \%$ of taxonomically identified adenophoreans, males were found nowhere and so parthogenesis is assumed as rule and according to the time limits of the research programme, the species of only two genera namely Xiphinema and Longidorus were distinguished by morphological features and among which some species are considered as new report in Kashmir valley on apple trees when others are already recorded. The results revealed that more or less population of plant parasitic adenophoreans were found associated with apple trees in all the apple orchards of each village in entire fruit belt of district North Kashmir. Mixed population from the composite soil samples comprised nine populations (communities species wise) in three groups. One group of adenophoreans belong to subfamily- Xiphinematinae, familyXiphinematidae of super family Longidoroidea, Thorne, 1935 and orderDorylaimida This group includes four species of genus Xiphinema viz. Xiphinama insigne; $X$. index; $X$ americanum and $X$. diversicaudatum. The other group of adenophoreans belong to sub-familyLongidorinae, family Longidoridae of same super family Longidoroidea and order Dorylaimida. It included three species of genus Longidorus viz. Longidorus elongatus $s ;$ L. mirus and L. brevicaudatus. The third group belonged to a group of mixed population named as other nematodes. It included some tylenchids which could not be excluded for the analysis of community structure in the soil sample in total. during extraction of adenophoreans by using some selected sieve sets with few modifications. This group also included some unidentified adenophoreans and some nematodes of fungal and bacterial feeders

Among the eight species of plant parasitic adenophorean population of two genera identified, maximum species are reported for the first time from Kashmir and from India on apple trees when some species are already known from Kashmir and from rest parts of India but on host other than apple trees. Xiphinema insigne, Xiphinema index and Longidorus elongatus were found predominant in orchards/ localities of entire Rafi-abad fruit belt. Almost $100 \%$ frequency with leading population in abundance of each of the three species was found in every fruit orchard while the rest of the identified species were also noted with more or less frequency and population density. The diversity and status of each species in detail is as under

\section{Xiphinema insigne}

$100 \%$ frequency of occurrence of Xiphinema insigne was found in each respective locality viz Ferozpora, Ladoora and Rebon. Mean population abundance of this species was found as 92.56, 61.11 \& 75.22 in localities Ferozpora, Ladoora and Rebon respectively with mean 76.03 in entire Rafi-abad ranging from 69.15 to 83.45 at $95 \%$ confidence interval and its relative frequency and relative prominence value in the entire fruit belt in comparison to other recorded adenophoreans was found as $12.16 \%$ and $22.39 \%$ respectively. (Table 1). Here highest absolute population was found in the apple orchards of Ferozpora (92.56) followed by Rebon (75.22) and lowest in Ladoora (75.22).9Table 1). Its 
pathogenic significance rank on the basis of prominence value (763.00) and importance value (46.67) is second in the entire Rafi-abad belt (Table 2) and on the basis of population number the diversion of energy flow of the adenophoreans was more in Rebon locality (2.002) followed by Ferozpora (1.93) and lowest in Ladoora (1.88) with overall diversion in the belt as 1.97 .

The presence of Xipheinema insigne showing $100 \%$ frequency with apple trees in all the fruit orchards is in accordance of the results recorded by Zaki and Manto (2003) during their survey on apple orchards of Baramullah and revealed $100 \%$ frequency with average population per $250 \mathrm{cc}$ soil ranging from 11145 whereas in our observation during the peak season of July, 2008, the average population per $250 \mathrm{cc}$ soil was 69.84 ranging from $66.17-73.51$ at $95 \%$ confidence interval.

This little fluctuation of the species with the apple trees can be possible because of involvement of different cultivars, age differences in plants as our survey is based on specific aged plants with homogenous topography and specific depth of plant rhizosphere in a particular season.

According to reports of H. K. Bajaj (1976), X. insigne was recorded, having temperature below 0 degree in winter while in other regions it may rise to $40-45{ }^{\circ} \mathrm{C}$ during summer, giving impression of higher tolerance of species. In some samples, its population constituted $90-95 \%$ of the total nematode fauna, attacking usually fruit trees.

Heavy population of $X$ insigne was also reported by Baghel and Bhatti (1982) around the routs of citrus fruits from Hissar, Haryana. Lamberti, and Roca (1987) reported distribution record of five most common species of Xiphinema including $X$. insigne around the roots of fruits crops in Pakistan.

\section{Xiphinema index}

The dagger nematode Xiphinema index was found as second important dominant vector after Xiphinema insigne on the basis of pathogenic significane rank and also it was found at par with Xiphinema insigne in frequency $(100 \%)$ in all the fruit orchards of every locality (village) in Rafi-abad (Table 1). The mean population abundance of Xiphinema index in 250 c.c. soil around the apple trees in Rafi-abad fruit belt was found as 72.69, 42.56 and 58.67 in Ferozpora, Ladoora and Rebon respectively with mean in the entire fruit belt as 58.04 ranging from 49.83 to 60.25 at $95 \%$ confidence interval and with $100 \%$ frequency in the entire fruit belt of Rafi-abad. The relative frequency and relative prominence value in comparison to other plant parasitic adenophoreans was found as $12.16 \%$ and $17.03 \%$ respectively (Table 2 ).

Looking over the status of Xiphinema index in the fruit belt, its highest population was found in the apple orchards of Ferozpora (72.89) followed by Rebon (58.67) and lowest population was recorded in Ladoora (42.56)

This species is cosmopolitan in woody plants and is historically important because it was the first nematode which was demonstrated to act as vector of soil borne viruses by Hewitt et al., (1958) who proved that this species transmits grapevine fan leaf virus

The X.index appearing in apple orchards comprise actually the soil samples of Mediterranean basin and which is considered the distribution centre of X.index and accordingly provides an explaination of our results in relation to climate and potential vegetation. This accords with the views of Antoniou (1981) as the association of X.index with soils of $\mathrm{pH}>7$ and poor in organic matter, which are generally the representative of the Mediterranean area, seems logical. 
Table.1

\begin{tabular}{|c|c|c|c|c|c|c|c|c|c|c|c|c|}
\hline \multirow{2}{*}{$\begin{array}{l}\text { Adenophorean } \\
\text { s }\end{array}$} & \multicolumn{4}{|c|}{ Ferozpora(9) } & \multicolumn{4}{|c|}{ Ladoora(9) } & \multicolumn{4}{|c|}{ Rebon(9) } \\
\hline & M.A. & P.P. & $\begin{array}{l}\text { 95\%.C. } \\
\text { I. }\end{array}$ & P.V. & M.A. & P.P. & $\begin{array}{l}95 \% . C . \\
\text { I. }\end{array}$ & P.V. & M.A. & P.P. & $\begin{array}{l}\text { 95\%.C. } \\
\text { I. }\end{array}$ & PV. \\
\hline $\begin{array}{l}\text { Xiphinema } \\
\text { insigne }\end{array}$ & 92.56 & 27.04 & $\begin{array}{l}79.65 \\
105.47\end{array}$ & 925.6 & 61.11 & 20.11 & $\begin{array}{c}52.78- \\
69.44\end{array}$ & 611.1 & 75.22 & 18.98 & $\begin{array}{l}65.41- \\
85.03\end{array}$ & $\begin{array}{c}752 \\
.2\end{array}$ \\
\hline X.index & 72.89 & 21.29 & $\begin{array}{l}61.91- \\
83.87\end{array}$ & 728.9 & 42.56 & 14.00 & $\begin{array}{c}32.99- \\
52.13\end{array}$ & 425.6 & 58.67 & 14.80 & $\begin{array}{l}39.71- \\
77.63\end{array}$ & $\begin{array}{c}586 \\
.7\end{array}$ \\
\hline X.americanum & 26.40 & 7.71 & $\begin{array}{c}19.28- \\
33.52\end{array}$ & 264.0 & 21.56 & 7.09 & $\begin{array}{c}14.14- \\
28.98\end{array}$ & 215.6 & 28.00 & 7.06 & $\begin{array}{l}21.62- \\
34.38\end{array}$ & $\begin{array}{c}280 \\
.0\end{array}$ \\
\hline $\begin{array}{l}\text { X.divrsicaudatu } \\
m\end{array}$ & 13.30 & 3.88 & $\begin{array}{l}5.82- \\
20.73\end{array}$ & $\begin{array}{c}108.6 \\
0\end{array}$ & 17.78 & 5.85 & $\begin{array}{c}13.16- \\
22.42\end{array}$ & 177.8 & 17.11 & 4.31 & $\begin{array}{l}12.58- \\
21.64\end{array}$ & $\begin{array}{c}171 \\
.1\end{array}$ \\
\hline X.basiri & 14.30 & 4.17 & $\begin{array}{l}3.89- \\
24.71\end{array}$ & 95.29 & 8.33 & 2.74 & $\begin{array}{l}5.32- \\
11.34\end{array}$ & 73.46 & 8.44 & 2.12 & $\begin{array}{l}4.01- \\
12.87\end{array}$ & $\begin{array}{l}68 . \\
91\end{array}$ \\
\hline $\begin{array}{l}\text { Longidorus } \\
\text { elongatus }\end{array}$ & 29.40 & 8.58 & $\begin{array}{c}15.07- \\
43.73\end{array}$ & $\begin{array}{c}277.1 \\
8\end{array}$ & 26.89 & 8.85 & $\begin{array}{c}16.45- \\
37.33\end{array}$ & $\begin{array}{c}253.5 \\
2\end{array}$ & 41.67 & 10.51 & $\begin{array}{c}29.43- \\
53.91\end{array}$ & $\begin{array}{c}416 \\
.7\end{array}$ \\
\hline L.mirus & 19.78 & 5.77 & $\begin{array}{l}9.74- \\
29.52\end{array}$ & $\begin{array}{c}211.1 \\
9\end{array}$ & 11.56 & 3.80 & $\begin{array}{l}6.46- \\
16.66\end{array}$ & $\begin{array}{c}101.9 \\
5\end{array}$ & 39.44 & 9.95 & $\begin{array}{l}31.35- \\
47.53\end{array}$ & $\begin{array}{c}394 \\
.4\end{array}$ \\
\hline L.brevicaudatus & 17.00 & 4.96 & $\begin{array}{c}12.14- \\
21.86\end{array}$ & $\begin{array}{c}160.2 \\
8\end{array}$ & 11.56 & 3.80 & $\begin{array}{l}6.85- \\
16.27\end{array}$ & $\begin{array}{c}101.9 \\
5\end{array}$ & 28.00 & 7.06 & $\begin{array}{l}19.56- \\
36.44\end{array}$ & $\begin{array}{c}280 \\
.0\end{array}$ \\
\hline $\begin{array}{l}\text { Other } \\
\text { nematodes }\end{array}$ & 56.67 & 16.55 & $\begin{array}{l}36.02- \\
77.32\end{array}$ & 566.7 & $\begin{array}{c}102.4 \\
4\end{array}$ & 33.72 & $\begin{array}{r}92.06- \\
112.82\end{array}$ & $\begin{array}{c}1024 . \\
4\end{array}$ & 99.78 & 25.17 & $\begin{array}{l}85.17- \\
114.39\end{array}$ & $\begin{array}{c}997 \\
.8\end{array}$ \\
\hline H. & 1.93 & & & & 1.884 & & & & 2.002 & & & \\
\hline
\end{tabular}

M.A=Mean abundance; P.P. =Percent population; C.I. =Confidence interval; P.V.=Prominance value; H. =Shannon wiener diversity index

Table.2

\begin{tabular}{|c|c|c|c|c|c|c|c|c|c|c|}
\hline Adenophoreans spp & A.D. & 95\% C.I. & A.F. & A.B. & R.D. & R.F. & RB. &. $\mathbf{P V}$ & IV & PSR \\
\hline Xiphinema insigne & $\begin{array}{l}76.30 \\
(1.88)\end{array}$ & $\begin{array}{c}69.15-83.45 \\
(1.84-1.92)\end{array}$ & $\begin{array}{c}100.0 \\
0\end{array}$ & $\begin{array}{l}128.1 \\
8\end{array}$ & 21.95 & 12.16 & $\begin{array}{l}12.5 \\
5\end{array}$ & 763.0 & $\begin{array}{l}46 . \\
67\end{array}$ & 2 \\
\hline X.index & $\begin{array}{l}58.04 \\
(1.76)\end{array}$ & $\begin{array}{c}49.83-66.25 \\
(1.70-1.82)\end{array}$ & $\begin{array}{c}100.0 \\
0\end{array}$ & $\begin{array}{l}167.7 \\
4\end{array}$ & 16.70 & 12.16 & $\begin{array}{l}16.4 \\
2\end{array}$ & 580.4 & $\begin{array}{l}45 . \\
28\end{array}$ & 3 \\
\hline X.americanum & $\begin{array}{l}25.32 \\
(1.40)\end{array}$ & $\begin{array}{c}21.61-29.03 \\
(1.33-1.46)\end{array}$ & $\begin{array}{c}100.0 \\
0\end{array}$ & 67.35 & 7.29 & 12.16 & 6.59 & 253.2 & $\begin{array}{l}26 . \\
04\end{array}$ & 6 \\
\hline X.divrsicaudatum & $\begin{array}{l}16.06 \\
(1.20)\end{array}$ & $\begin{array}{c}13.09-19.03 \\
(1.12-1.28)\end{array}$ & 88.89 & 69.06 & 4.62 & 10.81 & 6.76 & $\begin{array}{c}151.4 \\
1\end{array}$ & $\begin{array}{l}22 . \\
19\end{array}$ & 7 \\
\hline X.basiri & $\begin{array}{l}10.37 \\
(1.02)\end{array}$ & $\begin{array}{c}6.77-13.97 \\
(0.83-1.14)\end{array}$ & 62.97 & 47.81 & 2.98 & 7.65 & 4.68 & 82.28 & $\begin{array}{l}15 . \\
31\end{array}$ & 9 \\
\hline Longidorus elongatus & $\begin{array}{l}32.67 \\
(1.51)\end{array}$ & $\begin{array}{c}25.92-39.42 \\
(1.41)\end{array}$ & 92.59 & $\begin{array}{l}183.9 \\
3\end{array}$ & 19.40 & 11.28 & $\begin{array}{l}18.0 \\
0\end{array}$ & $\begin{array}{c}314.3 \\
6\end{array}$ & $\begin{array}{l}38 . \\
68\end{array}$ & 4 \\
\hline L.mirus & $\begin{array}{l}23.59 \\
(1.37)\end{array}$ & $\begin{array}{c}17.96-29.22 \\
(1.25-1.46)\end{array}$ & 88.89 & $\begin{array}{l}125.0 \\
3\end{array}$ & 6.79 & 10.81 & $\begin{array}{l}12.2 \\
4\end{array}$ & 22.41 & $\begin{array}{l}29 . \\
84\end{array}$ & 5 \\
\hline L.brevicaudatus & $\begin{array}{l}18.85 \\
(1.27)\end{array}$ & $\begin{array}{c}14.91-22.79 \\
(1.17-1.36)\end{array}$ & 88.89 & 43.73 & 5.42 & 10.81 & 4.28 & $\begin{array}{c}177.7 \\
2\end{array}$ & $\begin{array}{l}20 . \\
51\end{array}$ & 8 \\
\hline Other nematodes & $\begin{array}{l}86.30 \\
(1.94)\end{array}$ & $\begin{array}{c}75.59-97.01 \\
(1.88-1.99)\end{array}$ & $\begin{array}{c}100.0 \\
0\end{array}$ & $\begin{array}{l}188.1 \\
3\end{array}$ & 24.83 & 12.16 & $\begin{array}{l}18.4 \\
2\end{array}$ & 863.0 & $\begin{array}{l}55 . \\
41\end{array}$ & 1 \\
\hline
\end{tabular}

D.=Absolute density, C.I=confidence interval, R.D.=relative density, A.F.=absolute frequency. R.F.=relative frequency, P.V.=prominence value, $\mathrm{R} . \mathrm{Pv}=$ relative prominence value $\mathrm{H} .=$ Shannon weaver diversity density index, I.V=Importance value, PSR=Pathogenic significance rank. 
Table.3

Mean abundance, percent population, density and diversity index of genus Xiphinema and Longidorus vectors with apple trees in Rafi-abad (North Kashmir).

\begin{tabular}{|c|c|c|c|c|c|c|}
\hline \multirow{2}{*}{ Genus } & \multicolumn{2}{|c|}{.Ferozpora } & \multicolumn{2}{|l|}{ Ladoora } & \multicolumn{2}{|l|}{ Rebon } \\
\hline & M.A. & P.P. & M.A. & P.P. & M.A. & P.P. \\
\hline Xiphinema & 219.45 & 64.11 & 151.34 & 49.82 & 187.44 & 47.29 \\
\hline Longidorus & 66.18 & 19.33 & 50.01 & 16.46 & .109 .11 & 27.53 \\
\hline H. & \multicolumn{2}{|l|}{1.83} & \multicolumn{2}{|l|}{1.89} & \multicolumn{2}{|l|}{1.94} \\
\hline$\overline{\text { D. }}$ & \multicolumn{2}{|l|}{0.213} & \multicolumn{2}{|l|}{0.250} & \multicolumn{2}{|l|}{0.161} \\
\hline \% Moisture & \multicolumn{2}{|l|}{35} & \multicolumn{2}{|l|}{35} & \multicolumn{2}{|l|}{35} \\
\hline Organic Carbon & \multicolumn{2}{|l|}{1.2} & \multicolumn{2}{|l|}{0.98} & \multicolumn{2}{|l|}{1.2} \\
\hline SoilpH(1:2.5) & \multicolumn{2}{|l|}{7.1} & \multicolumn{2}{|l|}{7.0} & \multicolumn{2}{|l|}{7.3} \\
\hline Soil type & \multicolumn{2}{|l|}{ Clay loam } & \multicolumn{2}{|l|}{ Clay loam } & \multicolumn{2}{|c|}{ Clay loam } \\
\hline
\end{tabular}

H. =Shannon wiener diversity index, $\mathrm{D}=$ density, M.A=Mean abundance; P.P. =Percent population

And were also reported in potential Mediterrnean orchards of apple and peach trees with slightly acid soil in Region Central (Spain) by Navas \& Arias, 1986). As an ecoparasite it reduces the growth of trees and causes darkening of its roots (Cohn \& Orion, 1970).

\section{Longidorus elongatus}

Longidorus elongatus was found as third important adenophorean with its frequency 92 $59 \%$ in the entire Rafi-abad. The mean population abundance in the fruit orchards of Ferozpora, Ladoora and Rebon was found as29.40, 26.89 and 41.67 with its range in each locality as $15.07-43.73,16.45-37.33$ and 29.43-53.91 at $95 \%$ confidence interval respectively (Table1). The prominence value and importance value in Rafiabad fruit belt were found as 314.36 and 38.68 respectively. And similarly in entire Rafi-abad fruit belt the mean population abundance was found as 32.67 with range of $25.92-39.42$ at $95 \%$ confidence interval. Longidorus elongatus is a root ectoparasite and aggregates around growing roots (Whitehead and Hooper, 1970).Feeding at, or just behind root tips and causes a characteristic swelling or galling and a general stunting of the root system It transmit the Scottish strains of raspberry ring spot virus (RRV) (Taylor, 1962) and tomato black ring virus (TBRV) (Harrison et al., 1961).

\section{Xiphinema americanum}

The mean population abundance of this species in the apple orchards of Ferozpora, Ladoora and Rebon was found as 26.40, 21.56 and 28.00 ranging in each locality from 19.28-33.52, 14.14-28.98 and 21.62-34.39 respectively with over all mean population in the entire belt as 25.32 ranging from 21.6129.03 at $95 \%$ confidence interval. (TableT2) and similarly the prominence value and importance value of this species in the belt was found as 253.2 and 26.04 respectively. This species was already reported in very heavy population from the roots of ornamental plants at Nishat and Shalimar gardens of Srinagar (Bajaj, H. K. 1976). Xiphinema americanum is already reported by Khan, M.L. and Anju S Khana. 1997 from citrus trees of Himachal Pradesh.

\section{Other species of Xiphinema}

The mean abundance of Xiphinema diversicaudatum in each locality (Ferozpora, Ladoora and Rebon) was found as 13.30 (5.82-20.73), 17.78 (13.16-22.42) and 17.11 
(12.58-21.64) with over all mean abundance 16.06 (ranging from 13.09 to19.03) at $95 \%$ confidance interval. Its prominence value and importance value in comparison to other vectors in the belt was found as 151.41 and 22.19. And that of Xiphinema basiri it was $14.30(3.89024 .71), \quad 8.33 \quad(5.32-11.34)$ and 8.44 (4.01-12.87) with over all mean population abundance 10.37 (6.77-13.97) at $95 \%$ confidance interval respectively (Table 1.). This species is already reported by Khan, M.L. and Anju S Khana.1997 from citrus trees of Himachal Pradesh and by Waliullah and Koul in1997 from cherry trees of Kashmir, India.

\section{Other species of Longidorus}

The mean population abundance of Longidorus mirus in each locality was found as 19.78 (9.74-29.52), 11.56 (6.46-16.66) and 39.44 (31.35-47.53) with over all mean abundance in the belt as as 23.59 ranging from 17.96 to 29.22 at $95 \%$ confidence level. Its prominence value and importance value in the entire belt were recorded as 22.41 and 15.31 respectively. Similarly the mean population abundance of Longidorus brevicaudatus in each locality were found as 17.00 (12.14-21.86), 11.56 (6.85-16.27) and 28.00 (19.56-36.44) respectively with its overall mean abundance in the entire fruit belt as 18.85 ranging from 14.91-22.79 at $95 \%$ confidence interval. Its prominence value and importance value in the belt were recorded as 177.72 and 20.51 respectively.

Lamberti, et al., (1987) reported distribution record of five most common species of Xiphinema viz. $X$. basiri, $X$. brevicole, $X$. index, $X$. insigne and $X$. intermedium around the routs of fruits crops in Pakistan.

Viruses and their vectors have wide natural host range and. Incidence of such vectors depends on history of susceptible trees at a site and which is evident in our research programme because in all the apple localities nematodes can be due to the long prevalence or proximity of wild hosts in or nearby orchards such as arable weeds, hedge-row plants, other cultivable and wild fruit trees like apricot cherry, pear, plum walnut etc and willows, populous, other forest trees.

This data provides in detail and in a systematic manner the means of forecasting shadow of various dangerous plant parasitic nematodes like Xiphinema insigne, Xiphinema index and Longidorus elongatus, Xiphinema basiri, Xiphinema americanum, Xiphinema diversicaudatum and Longidorus mirus etc for coming events of tomorrow due to global warming as these vectors of viruses can give much significance of pathogenic importance besides other parasitic nematodes with the rise of temperature in the soil

\section{References}

Anonymous. 2008. Area and production statement for the year 20072008.Department of Horticulture, Jammu and Kashmir Govt.

Antoniou, M, 1981. "A nematological survey of vineyards in Cyprus". Nematol.medit.., 9: 133-137

Bajaj, H. K. and Jairajpuri, M. S. 1979. Review of the genus Xiphinema Cobb 1913 with the description of species from India. Records of the Zoological survey of India 75: 255-325.

Bandy, F. A; Sharma, M. K; Pandith, A. H and Bhat, M. Y. (2009).'Apple production in Kashmir valley: challenges and opportunities. "State level seminar on "Fruit Industry of Kashmir-Problems and Prospects" Compendium" pp 11-22

Cadman, C. H. 1963. Biology of soil borne viruses. Annual Review phytopathology, 1: 143 - 172. 
Chiristie, J. R. and Perry, V. G. 1951. Removing nematodes from soil. Proc. Helminth. Soc. Wash. 18: $106-108$.

Cobb, N.A. 1918. Estimating the nemapopulation of soil with special reference to sugarbeet and root-gall nemas Heterodera schachtii Schmidt and Haterodera radicicola (greef) Muller, and with a description of Tylencholaimus aequalis $\mathrm{n}$. $\mathrm{sp}$.

Cohn, E. and Orion, D.1970. The pathological effect of representative Xiphinema and Longidorus species on selected host plant. Nematologica. 16: 423 - 428. USDA Agriculture Technical circular Bur. Pt. Ind. U. S. Dept. Agric. 1: $1-48$

Harrison, B. D., Mowat, W.P \& Tayler, C.E. 1961. Transmission of a strain of tobacco black ring virus by Longidorus elongatus (Nematoda). Virology. 14: 480-485

Hewitt, W. B., Raski, D. J. and Goheen, A. C. 1958. Nematode vector of soil - borne fanleaf virus of grape vines. Phytopathology. 48: 586 - 595

Lamberti, F. and Roca, F. 1987. Present status of nematodes as vectors of plant viruses. Pp $321-328$ in vistas on Nematology. (J. A. Veech and D. W. Dickson, Eds) society of Nematologists, Hyattsville, Maryland, 509p.

Mohd Luqman Khan and Anju S. Khana. 1997. Nematodes associated with Citrus crops in Himachal Pradesh. Indian Journal of Nematology 27(2): 266-67

Navas, A and Arias, M. (1986.) On the distribution and ecology of Xiphinema index and $X$ italiae in Spain. Nematol.medit.14:207-215

Norton, D. C. 1978. Ecology of plant parasitic nematodes. John Wiley and Sons, Inc. New York USA 263 pp.

Pitcher, R. S. 1965. Inter - relationships of nematodes and other pathogens of plants. Helminthological Abstracts (Series B), 34: 1 - 17.

Taylor, C. E. 1962. Transmission of raspberry ringspot virus by Longidorus elongatus (deMan) (Nematoda; Dorylaimida). Virology, 17:493-494.

Thorne, G.1935.Notes on free living and plant parasitic nematodes. 11. In: Jairajpuri, M.S. and Ahmad, W. (eds) Dorylaimida Free living, Predaceous and Plant parasitic nematodes. Oxford and IBH Publishing Co. Ltd., New Delhi, Mumbai and Kolkata, pp228-229

Waliullah, M. I. S. and Kaul. V. 1997 Nematodes associated with cherry plants in Kashmir Valley India. Indian Journal of Nematology 27: 237.

Whiteehead, A.G \& Hooper, D.J. 1970. Needle nematodes (Longidorus spp.) and stubby-root nematodes (Trichodorus spp.) harmful to sugar beet and other field crops in England. Ann.Appl.Biol, 65: 339-350.

Zaki, F. A. and Mantoo, M. A. 2003. Plant parasitic nematodes associated with temperate fruit crops in Kashmir valley, India. Pest Management and Ecological Zoology, 11(1): 97-101

\section{How to cite this article:}

Lone G. M., F. A. Zaki, S. S. Pathania and Sajad Mohi. 2018. Population Abundance and Distribution of Ectoparasitic Plant Nematodes Associated with Apple Trees (Malus domestica) in Apple Belts of Kashmir, India. Int.J.Curr.Microbiol.App.Sci. 7(06): 3817-3824. doi: https://doi.org/10.20546/ijcmas.2018.706.449 